\title{
A new species of Eutatus Gervais (Xenarthra, Dasypodidae) from the Late Pleistocene of the Northern Pampean Region, Argentina
}

\author{
Luciano Brambilla and Damián Alberto Ibarra
}

\begin{abstract}
The genus Eutatus has been recently revised and only two species were recognized over detailed study of the characteristics of fixed osteoderms from the pelvic shield and other elements of postcranium: E. seguini, limited to the Bonaerian Stage/ Age and Lujanian Stage/Age, and E. pascuali, older than the latter, recognized in the Marplatan and Ensenadan Stage/Age. Here, we report a new species of Eutatini, Eutatus crispianii sp. nov., occurring in the Lujanian Stage/Age and described on the basis of the morphology of fixed osteoderms. Geometric morphometric analysis and statistical analysis of quantitative variables of these elements reveal significant differences between the new species and those previously reported.
\end{abstract}

Luciano Brambilla. Facultad de Ciencias Exactas, Ingeniería y Agrimensura. Universidad Nacional de Rosario (U.N.R.). Av. Pellegrini 250 - (S2000BTP) Rosario, Argentina. Ibrambilla@fbioyf.unr.edu.ar Damián Alberto Ibarra. Facultad de Ciencias Exactas, Ingeniería y Agrimensura. Universidad Nacional de Rosario (U.N.R.). Av. Pellegrini 250 - (S2000BTP) Rosario, Argentina. damianibarra341@hotmail.com

Keywords: South America; Lujanian; Armadillo; Eutatini; Osteoderm; Geometric Morphometrics

Submission: 30 April 2016 Acceptance: 28 February 2017

\section{INTRODUCTION}

Armadillos (Mammalia, Dasypodidae) belong to a particular group present in the faunas of Pampas from the late Miocene to Holocene (Vizcaíno and Bargo 1993; Vizcaíno et al., 1995, Soibelzon et al., 2010; Soibelzon and Leon, 2017). These organisms have, as one of their most notable features, an articulated bony carapace consisting of several hundred of interlocked osteoderms. Eutatus is a genus of extinct large armadillos that could have reached weights of around 50 kilograms
(Scillato-Yané et al., 1995; Vizcaíno and Bargo, 2013). Two thirds of the anterior region of the body was covered with mobile osteoderms arranged in about 14 articulated bands. The scapular shield was practically missing as it was rudimentary and limited to the flanks of the carapace. The posterior third was covered by a pelvic shield consisting of fixed osteoderms (Krmpotic et al., 2009a).

The remains of Eutatus are abundant from Chapadmalalan to Lujanian Stage/Age (Krmpotic and Scillato-Yané, 2007) and although there are some partial or complete carapaces, most speci- 
mens are composed of a single or a few osteoderms.

Paul Gervais (1867) was the first to describe Eutatus and the species $E$. seguini and then Ameghino (1881, 1889) and Bordas (1932) added new species: E. brevis, E. minutus, E. punctatus and E. ameghinoi (Krmpotic et al., 2009a). However, further review indicated that there are no characters that may support the validity of all these species. For example, E. minutus was described based on a group of small osteoderms that in fact belong to the anterior bands of the carapace of $E$. seguini (Krmpotic et al., 2009a). Given these circumstances the species were synonymized by Scillado-Yané (1982), who recognized only the type species E. seguini. Recently Krmpotic et al. (2009a) described a new species: E. pascuali, restricted to Marplatan-Ensenadan whereas $E$. seguini has been circumscribed to the BonaerianLujanian. Here we present a new species of armadillo of the Pampas belonging to the genus Eutatus; its remains were found in Santa $\mathrm{Fe}$, in sediments corresponding to the Saladillo Formation (Pleistocene-Holocene) (Parent et al., 2010). We carry out a statistical analysis on quantitative characters of fixed osteoderms, and we applied a geometric morphometric analysis to study the shape of osteoderms. These results support the description of the new species and strengthen knowledge on the morphology of osteoderms of Eutatus.

\section{MATERIAL AND METHODS}

We follow the chronological and biostratigraphic schemes of Cione and Tonni (2005). The terminology for description of osteoderms follows Krmpotic et al. (2009a).

The description of the new species was based on the study of dorsal osteoderms from the pelvic shield. Consequently, we adopted the criterion of comparing homologous regions used in Krmpotic et al. (2009a). The osteoderms of the holotype of E. crispianii sp. nov. were measured and compared with those from individuals of previously described species of Eutatus. A random effects model was used to estimate mean, variance between specimens, and variance within specimens of variables length and width from fixed osteoderms. The equation used is described: $y_{i j}=\beta+b_{i}+e_{i j}$; where $y_{i j}$ is the $i$-th observation of the variable under study in the specimen $\mathrm{j} ; \beta$, the average value of the variable under study (width or length); $b_{i}$, the random effect of the ith-specimen and $e_{i j}$ the random error. These parameters were used to test if there are significant differences in the length and/or width of osteoderms between the species of Eutatus. For this purpose, a total of 201 osteoderms of museum collections from Argentina were evaluated. Only the well-preserved fixed osteoderms of the dorsal region of the pelvic shield were analyzed.

Statistical analyses were performed using SPSS v20 (IBM Corp, 2011). Specimens previously assigned to $E$. pascuali and $E$. seguini were also analysed together in order to perform an estimation of parameters to genus level using the known species.

\section{Geometric Morphometric Analysis}

Osteoderms were analysed using geometric morphometric methods (Bookstein, 1991; O'Higgins, 2000; Mitteroecker and Gunz, 2009). Eighteen two-dimensional landmark coordinates were digitalized from pictures of osteoderms using TPSDig (Rohlf, 2003). Not all osteoderms available in collections were used in this analysis due to missing, or not visible landmarks in some of them. Osteoderms that come from a specific region, such as pelvic shield, were considered anatomically homologous.

Four landmarks and 14 semi-landmarks dispositions on osteoderms are shown in Figure 1.1. Semi-landmarks were placed along the contour of the central figure and at the side edges, and the TPSUtil routine was used to allow semi-landmarks to slide so as to minimize bending energy (Rohlf, 2004). Landmark configurations were aligned, scaled, transposed and rotated using the generalized least squares Procrustes superimposition method (Bookstein, 1991; Dryden and Mardia, 1998; Rohlf and Slice, 1990; Slice et al., 1996). Centroid size (CS), a geometric scale defined as the square root of the sum of squared distances between all landmarks and the configurations centroid (Zelditch et al., 2004), was calculated for each osteoderm. Differences in CS between sample groups were assessed using one-way ANOVA. Generalized Procrustes analysis does not completely remove the effect of size and the relationship between size and shape remains. Here, presence of allometry (i.e., shape changes that are related to increases in size; Mosimann, 1970) was assessed through a multivariate regression of shape (Procrustes coordinates) against centroid size of osteoderms (Bookstein, 1991; Monteiro, 1999) using MorphoJ (Klingenberg, 2011). The amount of variation explained by allometry was quantified as the percentage of the total shape 

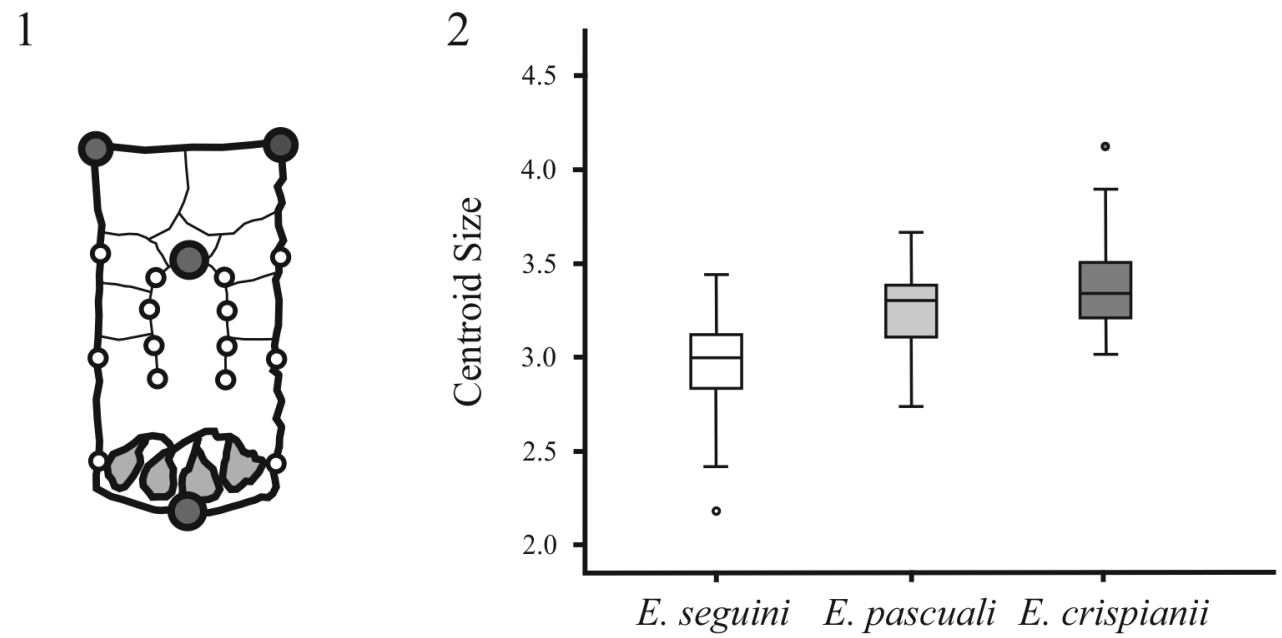

FIGURE 1. 1, Landmark configuration on schematic osteoderm of Eutatus; landmarks (dark gray circles) and semilandmarks (white circles); 2, Box-and-whisker plot showing centroid sizes of E. seguini, E. pascuali and E. crispianii. The central bar of each box represents the median of the population, while upper and lower bounds are 75th and 25th percentiles, respectively. Boxes show $50 \%$ of the population and whiskers extend showing the minimum and maximum values in a range of 1.5 times the length of the box. Circles mark the atypical values of CS located beyond to 1.5 times the box length distances.

variation accounted for the regression model (Klingenberg and Mclntyre, 1998), and the statistical significance of the model was assessed carrying out a permutation test $(10,000$ rounds). Significance of differences in shape between species was evaluated using a Procrustes Analysis of Variance (Procrustes ANOVA) in MorphoJ (analogous to a MANOVA) with 10,000 permutations. Then, canonical variates analysis (CVA) with 10,000 permutations were applied to the principal component scores to assess the discriminatory power of shape differences between groups. Shape differences along the first canonical variate axis were described using a wireframe graph.

\section{Institutional Abbreviations}

MACN, Sección Paleontología de Vertebrados, Museo Argentino de Ciencias Naturales "Bernardino Rivadavia" (MACN-A, Ameghino collection) (Ciudad Autónoma de Buenos Aires, Argentina); MLF, Museo de Ciencias Naturales "Florentino Ameghino" (Las Flores, Buenos Aires, Argentina); MLFM, Museo "Luis Francisco Muñiz" (Moreno, Buenos Aires, Argentina); MLP, División Paleontología de Vertebrados, Facultad de Ciencias Naturales y Museo de La Plata, Universidad Nacional de La Plata (La Plata, Buenos Aires, Argentina); MMP, Museo Municipal de Ciencias Naturales de Mar del Plata "Lorenzo Scaglia" (Mar del Plata, Buenos Aires, Argentina); MGPV; Museo
Provincial "Dr Ángel Gallardo" (Rosario, Santa Fe, Argentina); MUFyCA: Museo Universitario "Carlos y Florentino Ameghino" (Rosario, Santa Fe, Argentina); CICYTTP, Centro de Investigación Científica y Transferencia de Tecnología a la Producción (Diamante, Entre Ríos, Argentina).

\section{Materials}

MACN: 1999, 2772, 5238, 6035, 10160a, 10417, 10425, MACN-A: 1122, 1123, 1124, 1125, 1126, 1127, 1128; MGPV: E1; MLFM: 02-1143624200030, 02-11436242-00042, 02-11436242-150, 02-11436242-00337, 02-11436242-00352, 0211436242-00467, 02-11436242-00530; MUFyCA: 1179; MLP: 69-IX-5-3, 00-VIII-5-1, 69-VIII-19-1, 86VI-23-6, 69-VIII-1-6, 91-IV-25-1, 16-225, 86-VI-236, 27-I-1931; MMP: S-171, 1212; CICYTTP: PV-M2-367; MLF: 454

\section{SYSTEMATIC PALAEONTOLOGY}

Superorder XENARTHRA Cope, 1889 Order CINGULATA Illiger, 1811

Superfamily DASYPODOIDEA Gray, 1821

Family DASYPODIDAE Gray, 1821

Subfamily EUPHRACTINAE Pocock, 1924

Tribe EUTATINI Bordas, 1933

Genus EUTATUS Gervais, 1867

EUTATUS CRISPIANII sp. nov.

Figure 2.1

zoobank.org/48900334-80B2-49EC-993E-AD891D72E9A8 
1
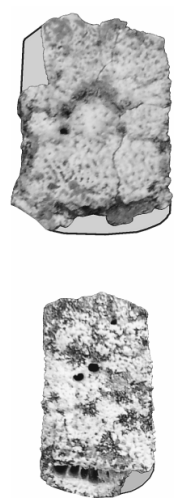
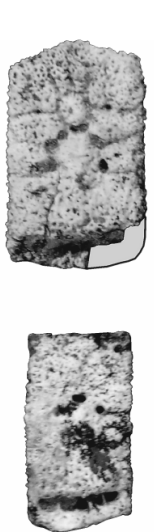
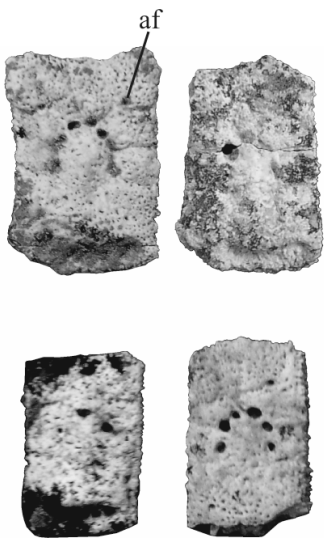

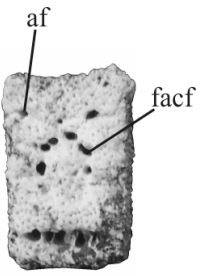

2

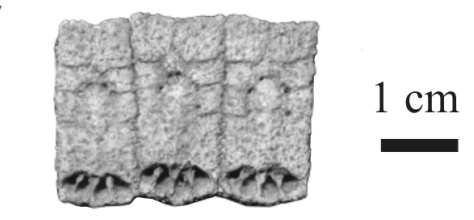

3
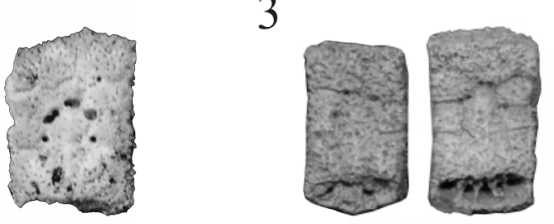

4

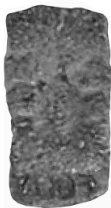

FIGURE 2. 1, Fixed osteoderms of Eutatus crispianii sp. nov. MGPV-E1; 2, E. seguini MACN10160a; 3, E. seguini MACN2772; 4, E. pascuali MMP1212. af, anterior foramina; facf, foramina around the central figure.

Holotype. MGPV-E1. Proximal fragment of tibia, a vertebra, osteoderms and fragmentary remains of ribs.

Etymology. The species is named in honor of Hector Crispiani; biochemist, founder of the Museo de Ciencias Naturales "Florentino Ameghino" from Las Flores; an active promoter of the paleontology, who formed an abundant collection of fossils of the Pleistocene from Argentina during his life.

Stratigraphic and Geographic Provenance. Remains were found in "Pueblo Esther" in southeast of the Rosario city, Santa Fe province, $\left(33^{\circ} 05^{\prime}\right.$ 22" $\mathrm{S}$ and $60^{\circ} 32^{\prime} 38^{\prime \prime} \mathrm{W}$ ) in a level that is $7 \mathrm{~m}$ beneath the current ground surface, near the left margin of the Paraná River. MGPV-E1 comes from the Saladillo Formation (Parent et al., 2010), corresponding to late Pleistocene and Holocene. The bearing sediments consist of sandy silt with abundant carbonate. These are located below loessic sediments that may be correlated with Tezanos Pinto Formation (OIS2) (Kröhling and Orpheus, 2002).

Diagnosis. The pelvic shield osteoderms (Figure 2.1) are larger than those of $E$. seguini and E. pascuali and show until 8 surface foramina around the central figure. Surface foramina are larger than the 4-6 exposed on the surface of the fixed osteoderms of E. seguini (Figure 2.2, 2.3), and they are remarkably different in size of the fine punctuations of E. pascuali (Figure 2.4). Foramina around the central figure of pelvic shield osteoderms in many cases converge to form an oval opening (Figure 2.1). Five-six little hair follicle foramina on the posterior region of fixed osteoderms differs from the long 4 hair follicle foramina of $E$. seguini. Additional surface foramina between the anterior minor figures on most of the fixed osteoderms (Figure 2.1).

\section{STATISTICS AND SHAPE ANALYSES}

\section{Statistical Analysis}

Specimens of the previously recognized species of Eutatus were used to build a database to estimate parameters of the genus, such as width mean and length mean of fixed osteoderms, as well as estimate the variation within and between specimens (Table 1).

The analysis of width and length of the fixed osteoderms revealed that $E$. crispianii sp. nov. presented significantly wider (t-test, $p<0.0001$ ) and longer osteoderms (t-test, $p<0.0001$ ) than those belonging to previously described species ( $E$. seguini + E. pascuali) (Krmpotic et al., 2009a). Figure 3 shows the correlation between width and length of the osteoderms of Eutatus. This reveals that many of the osteoderms of E. crispianii sp. nov. are outside the correlations ever observed between length and width in $E$. seguini or $E$. pascuali.

\section{Geometric Morphometric Analysis}

Differences in size were quantified by calculating centroid size of each osteoderm. Significant differences were observed between the three analysed species (ANOVA, $p<0.0001$ ). Osteoderms of E. crispianii sp. nov. showed the highest values of centroid size (Figure 1.2). E. crispianii sp. nov. are bigger than $E$. seguini (Tukey HSD test, $p<$ 0.0001 ) and also osteoderms of E. crispianii sp. nov. are bigger than E. pascuali (Tukey HSD test, $\mathrm{p}$ $<0.028$ ). Additionally, significant differences in centroid size between E. pascuali and E. seguini were observed $(p<0.0001)$ (Figure 1.2).

Multivariate regression of shape variables against CS revealed very weak allometric effect 
TABLE 1. Parameter estimates of the regression model for length and width of osteoderms of Eutatus. Mean and standard deviation (SD) calculated for E. crispianii sp. nov. Values are in millimeters.

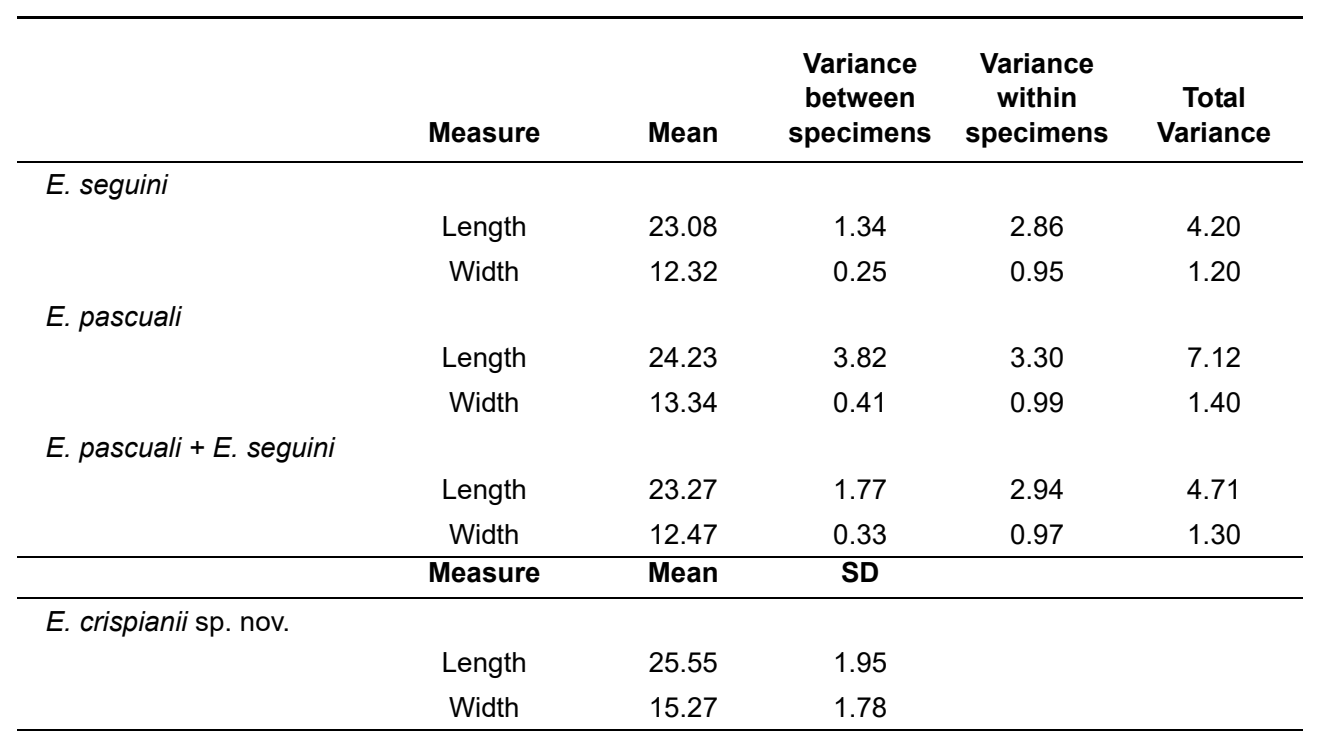

because only $3.4 \%$ of shape variations were explained due to changes in size $(p<0.0001)$.

\section{Shape of Fixed Osteoderms}

There were significant shape differences between osteoderms from Eutatus species (Procrustes ANOVA, $p<0.0001)$. Shape differences between them were separated successfully using CVA (Klingenberg et al., 2012) (Figure 4). CVA showed significant differences between $E$. seguini and $E$. crispianii (Mahalanobis distance $p<0.0001$ ) and among E. crispianii and E. pascuali (Mahala- nobis distance, $p<0.0001)$. Furthermore, very significant differences were observed in shape between E. pascuali and E. seguini (Mahalanobis distance, $p<0.0001$ ).

CVA showed that osteoderms of E. crispianii sp. nov. were located specifically in almost all cases in the positive values of the first axis. The most important shape variations along the CV1 were related to length of osteoderms and distance between the anterior border and the central figure (Figure 4). Positive values described osteoderms with shortening of the posterior region and exten-

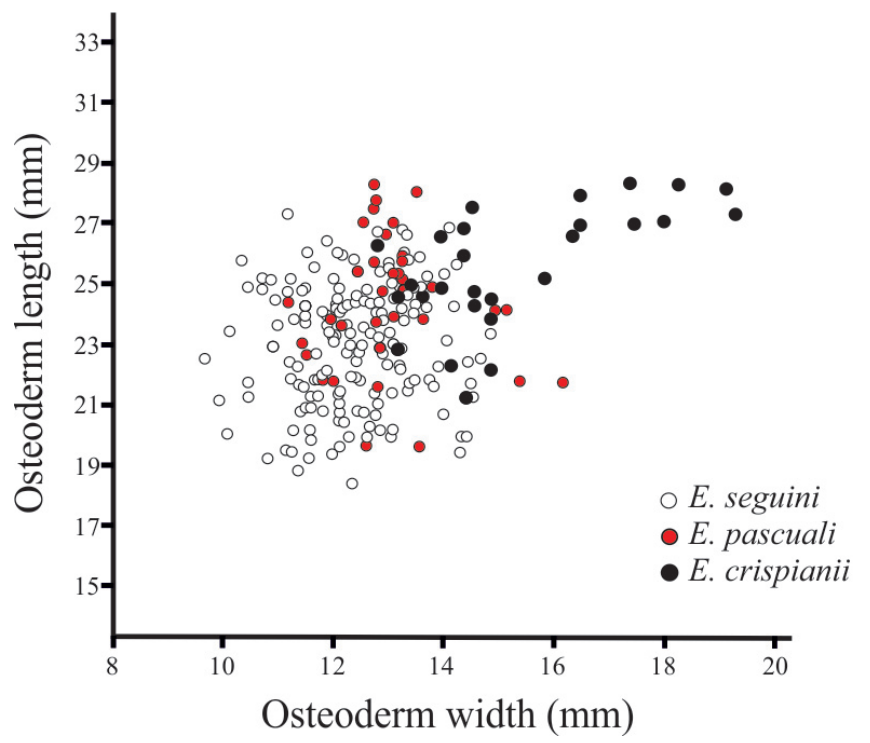

FIGURE 3. Bivariate plot showing relationship between the width and length of fixed osteoderms of E. crispianii sp. nov. (black circles), E. seguini (white circles) and E. pascuali (red circles). 


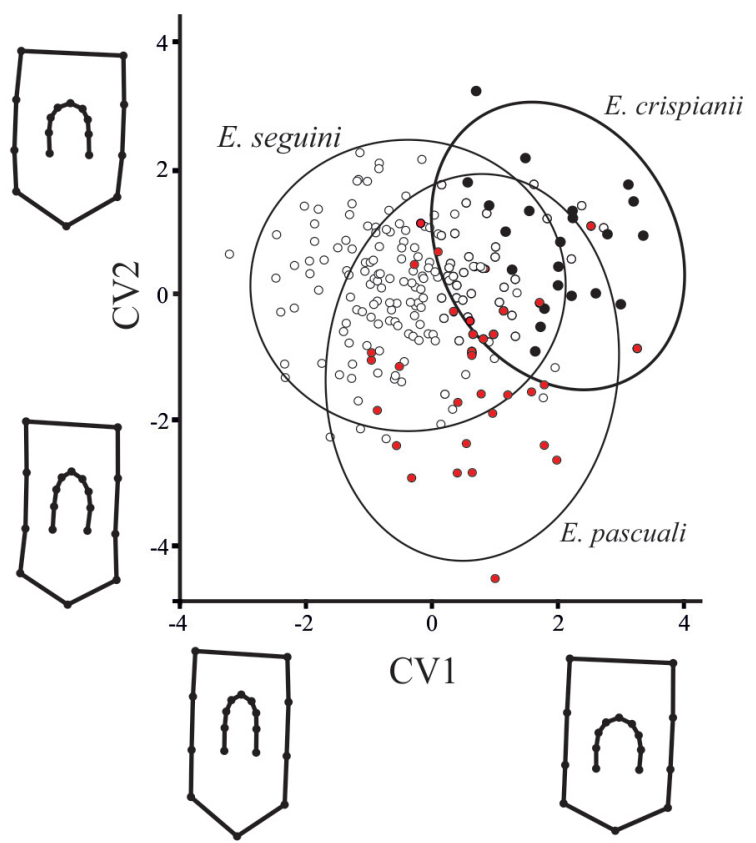

FIGURE 4. Scatterplot (CV1 versus CV2) from Canonical Variate Analysis of osteoderms of Eutatus. Shape change across axes is represented as wireframe for the positive and negative values. $95 \%$ confidence ellipse for E. seguini, E. pascuali and E. crispianii sp. nov. are shown. E. crispianii sp. nov. (black circles), E. seguini (white circles) and E. pascuali (red circles).

sion of the region between the anterior border and the central figure. The negative values were related to more elongated and narrow osteoderms with less distance between the anterior border and the central figure. Moreover, osteoderms in the negative values of CV1 display greater distance between the central figure and the hair follicle foramina, placed in posterior region (Figure 4).

The major differentiation along $\mathrm{CV} 2$ was related to general changes in width and length of osteoderms. Positive values of CV2 were related to shorter and wider osteoderms while negative values were related to long and thin osteodems. $E$. crispianii sp. nov. adopted mostly positive values of CV2.

\section{DISCUSSION}

In cingulates the morphology of the osteoderms has been largely the basis of most of systematic schemes (Vizcaíno and Bargo, 1993; Vizcaíno et al., 1995; Soibelzon et al., 2010). However, the variations that exist within osteoderms from the dorsal carapace of a single individual, in Dasypodidae and Glytodontidae, has been subject of a large number of non-valid species generating the consequent overestimation of the diversity of these groups (Krmpotic et al, 2009a; Zurita et al., 2016, Cruz et al., 2016). To reduce the variation existing in the osteoderms due to location within the carapace, we have focused on a specific type of osteoderms from homologous regions between specimens. Moreover, it must be noted that in some cingulates, like Glyptodon spp., ontogenetic changes affect the morphology of the osteoderms, leading to a correlation between their size and their shape. This has also led to the creation of nonvalid species based on juvenile or sub-adult specimens. This subject was recently reviewed by several authors (Zurita et al., 2011, 2016; Cruz et al., 2016) and the shape of osteoderms from a juvenile specimen of Glyptodon sp. were described (Luna and Krapovickas, 2011). However, detailed studies on osteoderms of extant armadillos or Glyptodontidae using geometric morphometric techniques has not been tackled. In the present study we analysed the largest number of known osteoderms of Eutatus to cover the widest range of variations.

When we analysed the variation in shape versus the size of the osteoderms (Centroid Size), we observed that the main changes in shape are related very weakly to size. This shows that there are no severe changes in shape by varying the size of the osteoderms. In other words, variations in the size of the osteoderms does not modify to a large degree the shape of the osteoderms and the differences between E. seguini, E. pascuali and $E$. crispianii sp. nov. are due to intrinsic characteristics of each species.

Although some degree of overlap was observed in CVA (Figure 4), the differences in shape between the three species were statistically significant.These overlaps were expected due the intra-individual variation and the resultant high degree of variation in shape within each group.

E. crispianii has the biggest osteoderms, these surpass the width and length of those of $E$. pascuali and even of $E$. seguini, the other Lujanian specie (Figure 3). It is necessary to emphasize that the correlation between width and length of osteoderms of Eutatus showed that those of E. crispianii sp. nov were differentiable from $E$. seguini and $E$. pascuali, while the two latter were indistinguishable from each other (Figure 3).

Statistical analysis showed that the width of the fixed osteoderms of the new species was significantly higher than the average of the previously described species (Table 1). Length variable also was on average higher than that observed for the heretofore known species of Eutatus (Table 1). In 
both cases, the probability that the osteoderms represented by the specimen MGPV-E1 come from a known species is negligible considering their width $(p<0.0001)$ and length $(p<0.0001)$. It is necessary to emphasize that when analyzing the correlation between width and length of osteoderms of Eutatus (Figure 3), those of E. crispianii sp. nov were differentiable from $E$. seguini and $E$. pascuali, while the two latter were indistinguishable from each other.

From the morphological point of view, the presence of additional foramina near the anterior border (Figure 2.1, af), among the minor figures of fixed osteoderms, and away from the central figure, is a character that had not yet been observed in the genus Eutatus, although this feature is present in another member of the subfamily Euphractinae: Chaetophactus villosus (Krmpotic et al., 2009b; Francia and Ciancio, 2013).

The presence of abundant foramina was proposed as an adaptation to cold and dry climate in E. seguini (Krmpotic et al., 2009a). The greater abundance of exposed surface foramina, as well as its larger size in E. crispianii sp. nov. would be aligned with the arid or semi-arid climates occurred in lapses during the Lujanian Stage/Age in the northern Pampean region (Iriondo and García, 1993).

\section{CONCLUSIONS}

Landmark-based geometric morphometric analysis used in this study allowed evaluating morphological characteristics underlying the osteoderms of Eutatus species and include the complexity of the particular variation present in each osteoderm. This technique was suitable to include and assess the variation in shape that occurs not only between osteoderms of different specimens but also between neighboring osteoderms from a specific region within a same shield. Future research might explore the diversity of osteoderm of other Cingulata such as species of the family Glyptodontidae, which present great diversity in the osteoderms shape, even within the same specimen, in order to use this tool with systematics purposes.

Here we show that the larger size of the osteoderms, the large number and large size of the surface foramina, the short opening of the hair follicle foramina, and the novel presence of the additional foramina near the anterior border of the osteoderms are characters that are only combined in E. crispiannii.
Finally, the results presented here provide abundant evidence to consider E. seguini, E. pascuali and E. crispianii sp. nov. as separate taxonomic entities. The description of a new species of Eutatus increases the knowledge on the diversity achieved by the genus in the late Pleistocene. This also provides new clues about the organisms that inhabited the north of Pampean region, where faunistic association might have been somewhat different from those classic Lujanian faunas widely studied in the center and south of Pampean region (Tonni et al., 2003; Cione et al., 2009).

\section{ACKNOWLEDGMENTS}

We thank M. Reguero (MLP), A.A. Kramarz and S.M. Alvarez (MACN), C. Schreiber (MLFM), and H.G. Crispiani (MLF) for facilitating access to collections of their institutions. We thank M. Ciancio for critically reading and improving earlier drafts of the manuscript. We also express our gratitude to M.L. Irrazábal, F. García, G. Giordano, L. Rey and M.B. Molinengo for recovery and technical preparation of MGPV-E1. Thanks to H. Bottai and J.J. Ivancovich for their help in statistical analysis. J.L. Aguilar, J.I. Verdón of Paleontological Museum of San Pedro "Fray Manuel de Torres" and E. Aguirre of Museo de Antropología e Historia Natural "Los Desmochados" for their cooperation during the search for specimens. The comments of the editor J. Louys and three anonymous reviewer improved this work by providing constructive reviews.

\section{REFERENCES}

Ameghino, F. 1881. La antigüedad del hombre en el Plata. 2:1-557. París-Buenos Aires.

Ameghino, F. 1889. Contribución al conocimiento de los mamíferos fósiles de la República Argentina. Actas de la Academia Nacional de Ciencias (Córdoba), 6:11028.

Bookstein, F.L. 1991. Morphometric Tools for Landmark Data: Geometry and Biology. Cambridge University Press, New York.

Bordas, A.F. 1932. Consideraciones sobre el género Eutatus y descripción de una nueva especie. Physis, $11: 142-143$.

Bordas, A.F. 1933. Notas sobre los Eutatinae. Nueva subfamilia extinguida de Dasypodidae. Anales Museo Nacional Historia Natural, 37:583-614. (Paleontología, Publ. N 65). Buenos Aires.

Cione, A.L. and Tonni, E.P. 2005. Bioestratigrafía basada en mamíferos del Cenozoico superior de la provincia de Buenos Aires, Argentina. Geología y recursos minerales de la provincia de Buenos Aires, 11:183200. 
Cione, A.L., Tonni, E.P., and Soibelzon, L. 2009. Did humans cause the Late Pleistocene-Early Holocene mammalian extinctions in South America in a context of shrinking open areas? pp. 125-144. In Haynes, G (ed.), American Megafaunal Extinctions at the End of the Pleistocene. Springer, Netherlands.

Cope, E.D. 1889. The Edentata of North America. American Naturalist, 23:657-664.

Cruz, L.E., Fernicola, J.C., Taglioretti, M., and Toledo, N. 2016. A reassessment of the taxonomic status of Paraglyptodon Castellanos, 1932 (Mammalia, Cingulata, Glyptodontia). Journal of South American Earth Sciences, 66:32-40.

Dryden, I.L. and Mardia, K.V. 1998. Statistical Shape Analysis. Wiley, Chichester.

Francia, A. and Ciancio, M.R. 2013. First record of Chaetophractus villosus (Mammalia, Dasypodidae) in the late Pleistocene of Corrientes Province (Argentina). Revista del Museo de La Plata, 13:1-9.

Gervais, P. 1867. Sur une nouvelle collection d'ossements fossiles de mammifères recueillie par M. Fr. Seguin dans la Confédération Argentine. Comptes rendus des séances de l'Académie des Sciences, 65:279-282.

Gray, J.E. 1821. On the natural arrangement of vertebrose animals. London Medical Repository, 15:296310.

IBM Corp. 2011. IBM SPSS Statistics for Windows, Version 20.0. Armonk, NY: IBM Corp.

Illiger, K. 1811. Prodromus Systematics Mammalium et Ayium. Salfled, Berlin.

Iriondo, M. and Garcia, N. 1993. Climatic variations in the Argentine plains during the last 18,000 years. Palaeogeography, Palaeoclimatology, Palaeoecology, 101:209-220.

Klingenberg, C.P. 2011. MorphoJ: an integrated software package for geometric morphometrics. Molecular Ecology Resources, 11:353-357.

Klingenberg, C.P., Duttke, S., Whelan, S., and Kim, M. 2012. Developmental plasticity, morphological variation and evolvability: a multilevel analysis of morphometric integration in the shape of compound leaves. Journal of Evolutionary Biology, 25:115-129.

Klingenberg, C.P. and Mclntyre, G.S. 1998. Geometric morphometrics of developmental instability: analyzing patterns of fluctuating asymmetry with Procrustes methods. Evolution, 5:1363-1375.

Krmpotic, C.M., Carlini, A.A., and Scillato-Yané, G.J. 2009a. The species of Eutatus (Mammalia, Xenarthra): Assessment, morphology and climate. Quaternary International, 210:66-75.

Krmpotic, C.M., Ciancio, M.R., Barbeito, C., Mario, R.C., and Carlini, A.A. 2009b. Osteoderm morphology in recent and fossil euphractine xenarthrans. Acta Zoologica, 90:339-351.

Krmpotic, C.M. and Scillato-Yané, G. 2007. Rectificación de la procedencia estratigráfica de Eutatus seguini Gervais, 1867 (Xenarthra, Dasypodidae). Ameghiniana, 44:637-638.
Kröhling, D. and Orfeo, O. 2002. Sedimentología de unidades loéssicas (Pleistoceno Tardio-Holoceno) del centro-sur de Santa Fe. Revista de la Asociación Argentina de Sedimentología, 9:135-154.

Luna, C.A. and Krapovickas, J.M. 2011. Primer registro de un ejemplar juvenil de Glyptodon sp.(Cingulata, Glyptodontidae) del Cuaternario de la provincia de Córdoba, Argentina. Mastozoología Neotropical, 18:135-141.

Mitteroecker, P. and Gunz, P. 2009. Advances in geometric morphometrics. Evolutionary Biology, 36:235-247.

Monteiro, L.R. 1999. Multivariate regression models and geometric morphometrics: the search for causal factors in the analysis of shape. Systematic Biology, 48:192-199.

Mosimann, J.E. 1970. Size allometry: size and shape variables with characterization of the lognormal and generalized gamma distributions. Journal of the American Statistical Association, 65:930-945.

O'Higgins, P. 2000. The study of morphological variation in the hominid fossil record: biology, landmarks and geometry. Journal of Anatomy, 197:103-120.

Parent, H., Polare, M., and Lattuca, F. 2010. Estratigrafía del Cuaternario del sur de la Provincia Santa Fe, Argentina. Boletín del Instituto de Fisiografía y Geología, 72:42-47.

Pocock, R.I. 1924. The external characters of the South American Edentates. Proceedings Zoological Society London, 2:883-1031.

Rohlf, F.J. 2003. Bias and error in estimates of mean shape in geometric morphometrics. Journal of Human Evolution, 44:665-683.

Rohlf, F.J. 2004. tpsUtil version 1.26. New York: Department of ecology and evolution, State University, Stony Brook.

Rohlf, F.J. and Slice, D. 1990. Extensions of the Procrustes method for the optimal superimposition of landmarks. Systematic Zoology, 39:40-59.

Scillato-Yané, G. 1982. Los Dasypodidae (Mammalia, Edentata) del Plioceno y Pleistoceno de Argentina. Tesis Doctoral $\mathrm{N}^{\circ}$ 406, Facultad de Ciencias Naturales y Museo, Universidad Nacional de La Plata.

Scillato-Yané, G. J., Carlini, A. A., Vizcaíno, S. F., and Ortiz Jaureguizar, E. 1995. Los xenarthros. Evolución biológica y climática de la Región Pampeana durante los últimos cinco millones de años. Un ensayo de correlación con el Mediterráneo Occidental, 15, 311-337.

Slice, D.E., Bookstein, F.L., Marcus, L.E., and Rohlf, F.J. 1996. Appendix I: a glossary for geometric morphometrics, p. 531-551. In Slice, D. (ed.), Advances in morphometrics. Plenum Press, New York.

Soibelzon, E., Miño-Boilini, Á.R., Zurita, A.E., and Krmpotic, C.M. 2010. Los Xenarthra (Mammalia) del Ensenadense (Pleistoceno inferior a medio) de la Región Pampeana (Argentina). Revista mexicana de ciencias geológicas, 27:449-469.

Soibelzon, E. and Leon, D.C. 2017. Effects of climatic oscillations on the faunas. The Holocene Thermal 
Maximum and the displacement of armadillos in Argentina: Anatomical features and conservation. Journal of Archaeological Science: Reports, 11:9098.

Tonni, E.P., Cione, A.L., and Soibelzon, L.H. 2003. The Broken Zig-Zag: Late Cenozoic large mammal and tortoise extintion in South America. Revista del Museo Argentino de Ciencias Naturales, 5:1-19.

Vizcaíno, S.F. and Bargo, M.S. 1993. Los armadillos (Mammalia, Dasypodidae) de La Toma (Partido de Coronel Pringles) y otros sitios arqueológicos de la Provincia de Buenos Aires. Consideraciones paleoambientales. Ameghiniana, 30:435-443.

Vizcaíno, S.F. and Bargo, S.M. 2013. Limb reconstruction of Eutatus seguini (Mammalia: Xenarthra: Dasypodidae). Paleobiological implications. Ameghiniana, 40:89-101.

Vizcaíno, S.F., Pardiñas, U.F.J., and Bargo, M.S. 1995. Distribución de los armadillos (Mammalia, Dasypodi- dae) en la región Pampeana (Republica Argentina) durante el Holoceno. Interpretación paleoambiental. Mastozoología Neotropical, 2:149-166.

Zelditch, M.L., Donald, L., Swiderski, H., Sheets, D., and Fink, W.L. 2004. Geometric Morphometrics for Biologists: a Primer. Elsevier Academic Press, London.

Zurita, A.E., Oliveira, E.V., Torino, P., Rodriguez-Bualó, S.M., Scillato-Yané, G.J., Luna, C., and Krapovickas, J. 2011. On the taxonomic status of some Glyptodontidae (Mammalia, Xenarthra, Cingulata) from the Pleistocene of South America. Annales de Paléontologie, 97:63-83.

Zurita, A.E., Taglioretti, M., De los Reyes, Martin., Cuadrelli, F., and Poire, D. 2016. Regarding the real diversity of Glyptodontidae (Mammalia, Xenarthra) in the late Pliocene (Chapadmalalan Age/Stage) of Argentina. Anais da Academia Brasileira de Ciencias, 88:809-821. 